\title{
Intramuscular Connective Tissue Components Contributing to Raw Meat Toughness in Various Porcine Muscles
}

\author{
Tadayuki Nishiumi, Ryuji Kunishima, Toshihide Nishimura \\ and Shigeru YosHIDA
}

Faculty of Applied Biological Science, Hiroshima University, Higashi-Hiroshima-shi 724

(Received November 11, 1994)

\begin{abstract}
Shear force value, contents of intramuscular collagen, elastin and proteoglycans and heat solubility of collagen were determined on eight different muscles from miniature pigs in order to confirm the relationship between raw meat toughness and intramuscular connective tissue components. Semitendinosus and semimenbranosus muscles were significantly tougher than any other muscles tested $(\mathrm{P}<0.05)$. The strongest correlations $(\mathrm{P}<0.001)$ were found between elastin content or heat solubility of collagen and raw meat toughness. No meaningful links could be found between textural quality of the raw meat and heat-labile collagen content or the proportion of ground substance relative to fibrous connective tissue $(\mathrm{P}>0.05)$. Significant differences were seen, however, between the total collagen or proteoglycan content and the relative tougness of each muscles $(P<0.01, P<0.05)$, respectively.

The results suggest that the maturity of intramuscular collagen with a stable intermolecular cross-linking and the accumulation of elastin may be directly contributing to meat toughness.

Anim. Sci. Technol. (Jpn.) 66 (4) : 341-348, 1995

Key words : raw meat toughness, connective tissue, collagen, elastin, proteoglycan
\end{abstract}

Among appearacnce, color, flavor, juiciness, taste, texture and so on, tenderness has been shown to be most important factor contributing to the acceptability of meat by consumers ${ }^{2)}$. The meat animal carcasses contains over 600 muscles which in general terms may be considered to be similar in composition. However, it is known that certain cuts of meat such as shin are tough, whilst others such as fillet steak are nearly always the most tender. Both so-called actomyosin toughness attributable to the myofibrillar contractile apparatus and socalled background toughness attributable to the connective tissue present, organizing into stable supramolecular structures in muscle are involved in meat toughness ${ }^{22}$.

Majority of the studies on meat texture have been carried out in cooked meat because commonly eating and having a greater difference of thoughness than the raw one. Howcver, it is necessary to investigate the raw meat toughness for elucidations of relationships between the structural components and physiological properties of muscles and/or effects of the components on postmortem changes during conversion of muscle to meat. Thus, in the present study, the raw meat toughness is examined. HATAE et al. ${ }^{14)}$, determing both firmness of the raw and cooked muscles of five fish species, reported that the species with the softer raw meat textures gave a firmer on cooking. On the other hand, a positive relationship between the raw and cooked meat toughness is considered in beef ${ }^{17}$. 
Intramuscular connective tissues are the perimysium which surrounds the muscle fiber bundles and groups of bundles, and the endomysium which surrounds each muscle fiber as basement membrane. The main intra. muscular connective tissue components are fibrous collagen and elastin and amorphous ground substances, such as proteoglycans and glycosaminoglycans. Studies on the effects of intramuscular connective tissue have been chiefly focused on collagen because of its abundant existence and structural firmness, but all the roles of connective tissue components in meat toughness have not been defined.

The objectives of this study were to determine the raw meat toughness of various porcine muscles, to determine the relative concentrations of collagen, elastin and proteoglycans in various porcine muscles, and to find out the direct or indirect relationships between the raw meat toughness and these connective tissue components in procine muscle.

\section{Materials and Methods}

Muscles: Eight muscles were used to obtain a wide range of meat texture and connective tissue contents. The muscles were: longissimus dorsi (LD), triceps brachii (TB), supraspinatus (SS), infraspinatus (IS), gluteus medius (GM), biceps femoris (BF), semitendinosus (ST) and semimembranosus (SM).

Three 418-day-old Göttingen miniature pigs of the same litter were slaughtered by exsanguination. Following a 7-day conditioning period at $4^{\circ} \mathrm{C}$, these muscles were excised from each carcass. The individual muscles were dissected and trimmed of all visible exter nal fat and epimysium, partially frozen and cut into $10 \times 10 \times 30 \mathrm{~mm}^{3}$ pieces with the muscle fiber direction along the long axis. The pieces were used for texture measurements.

Texture measurements: Shear force values for the $10 \times 10 \times 30 \mathrm{~mm}^{3}$ pieces from eight muscles were determined using a Rheometer (R-DM-2, San-Kagaku Co., Tokyo) with a knife-blade. A crosshead speed and full scale load of $40 \mathrm{~mm} / \mathrm{min}$ and $2 \mathrm{~kg}$, respectively were used. Pieces were placed with their long direction across the shear blade; the muscles fibers were cut at right angles by the blade. The cross-sectional area of each piece was 1 $\mathrm{cm}^{2}$. Twenty shears per muscle per carcass were obtained (i.e. 60 shears per muscle). Peak shear force values were expressed in ' $\mathrm{g} / \mathrm{cm}^{2}$.

Chemical analyses: After the determination of shear force value, the muscle samples were minced three times through a meat chopper with $3 \mathrm{~mm}$ size holes. A part of the mince (approximately $20 \mathrm{~g}$ ) was retained for elastin analysis, and the remainder was dried and defatted in chloroform-methanol mixture solution in a 2:1 ratio. The dried-defatted matter (DDM) was weighed to determine moisture and fat losses and then powdered in a grinder mill (ANM-150, Nitto-Kagaku Co., Tokyo). The DDM was used for chemical analyses of the intramuscular connective tissue components.

The powdered DDM was heated for $70 \mathrm{~min}$ at $77^{\circ} \mathrm{C}$ in distilled water and separated into heatsoluble and insoluble fractions by twice centrifugations following the procedure outlined by $\mathrm{HILL}^{15}$. The individual muscle fractions were then hydrolyzed in $6 \mathrm{~N} \mathrm{HCl}$ for $24 \mathrm{~h}$ at $110^{\circ} \mathrm{C}$ and the hydroxyproline contents of the hydrolysates were determined ${ }^{4)}$. Hydroxyproline values were converted to insoluble collagen using a factor of $7.25^{13)}$ and to soluble collagen using a factor of 7.52 based on absence of elastin ${ }^{9)}$. The total concentration of intramuscular collagen for each sample was determined by adding the amounts of heat-soluble and insoluble collagen, and the percentage of soluble collagen in each muscle sample was calculated.

Elastin was isolated from each of the eight muscles using the procedure outlined by Cross et al. ${ }^{8)}$. Briefly, the minced muscle samples were weighed and exhaustively extracted with $1.1 \mathrm{M} \mathrm{KI}$ in $0.1 \mathrm{M}$ phosphate buffer, pH 7.4, to ensure complete removal of myofibrillar and 
sarcoplasmic proteins. Following fat extraction with an excess of $2: 1$ chloroform-methanol and removal of the solvent, the residue was selectively hydrolyzed in $0.1 \mathrm{~N} \mathrm{NaOH}$ for $50 \mathrm{~min}$ at $98^{\circ} \mathrm{C}$ to remove the collagen portion of the connective tissue fraction. The remaining residue was hydrolyzed in $6 \mathrm{~N} \mathrm{HCl}$ and the hydroxy proline was quantitated as mentioned above. The concentration of intramuscular elastin was determined by multiplying the hydroxyproline content by 66.225 based on the report of the amino acid composition of the intramuscular elastin ${ }^{83}$.

For the determination of uronic acid, as an index of proteoglycans, proteins contained in the muscles were digested with papain in advance according to the report of ALEXANDER et al. ${ }^{1)}$. Following an activation by incubating the papain (type III, Sigma) with 0.1 M EDTA, the powdered DDM was extracted with the activated papain solution for $24 \mathrm{~h}$ at $65^{-70^{\circ} \mathrm{C}}$ and the supernatant was collected by centrifugation. The residue washed with $0.1 \mathrm{M}$ phosphate buffer, pH 6.4 containing $0.3 \mathrm{M} \mathrm{NaCl}$ was re-centrifuged for the collection of the supernatant. Uronic acid content in the both supernatant fractions was estimated using the procedure of BrTter and $\mathrm{MUIR}^{5\rangle}$ with glucuronolactone as a standard.
Statistical analysis: Data was analysed by analysis of variance. Muscle group means were separated at 5\% level of signiffcance using the Tukey's Studentized multiple range test ${ }^{24)}$. Linear correlation coefficients were computed between the shear force value, the contents of each of the intramuscular connective tissue components, heat solubility of collagen and the proportion of uronic acid relative to hydroxy proline.

\section{Results and Discussion}

Meat toughness: Textural difference of meat have been assessed either by subjective sensory panel or objective mechanical testing, with many arguments. In the present study, a Rheometer with a knife-blade was used for objective determination of raw meat toughness. As shown in Table 1, peak shear force values in both ST and SM were significantly higher than in the other six muscles $(\mathrm{P}<0.05)$. This data supports the earlier findings in cooked meat ${ }^{17)}$ and in raw meat ${ }^{20)}$, however, it is difficult to detect a textural difference in raw meat compared with cooked meat.

Chemical properties of intramuscular connective tissue components: As shown in Table 1, the total concentrations of intramuscular collagen varied among muscles from $4.34 \pm 0.73 \mathrm{mg} /$

Table 1. Physical and chemical measurements of eight different muscles from miniature pigs ${ }^{1}$

\begin{tabular}{|c|c|c|c|c|c|c|c|}
\hline Muscles & $\begin{array}{l}\text { Shear } \\
\text { force } \\
\text { vglue } \\
\left(\mathrm{g} / \mathrm{cm}^{2}\right)\end{array}$ & $\begin{array}{c}\text { Collagen } \\
\text { content } \\
(\mathrm{mg} / \mathrm{g})\end{array}$ & $\begin{array}{c}\text { Heat-labile } \\
\text { collagen } \\
\text { content } \\
(\mathrm{mg} / \mathrm{g})\end{array}$ & $\begin{array}{c}\text { Elastin } \\
\text { content } \\
(\mu g / g)\end{array}$ & $\begin{array}{l}\text { Uronic acid } \\
\text { content } \\
(\mu \mathrm{g} / \mathrm{g})\end{array}$ & $\begin{array}{c}\text { Heat } \\
\text { solubility } \\
\text { of collagen } \\
(\%)\end{array}$ & $\begin{array}{l}\text { Uronic } \\
\text { acid/ } \\
\text { Hydro- } \\
\text { xyproline }\end{array}$ \\
\hline semitendinosus & $558 \pm 51^{a}$ & $8.62 \pm 1.49^{\mathrm{ab}}$ & $1.03 \pm 0.12^{b}$ & $239 \pm 31^{a}$ & $537 \pm 59^{a}$ & 11.90 & 0.45 \\
\hline semimembranosus & $507 \pm 51^{\star}$ & $6.61 \pm 1.30^{a b c}$ & $0.88 \pm 0.15^{b}$ & $178 \pm 27^{b}$ & $534 \pm 79^{a}$ & 13.37 & 0.59 \\
\hline supraspinatus & $444 \pm 51^{b}$ & 7. $76 \pm 0.91^{\mathrm{ab}}$ & 1. $24 \pm 0.20^{\mathrm{ab}}$ & $163 \pm 22^{b c}$ & $398 \pm 34^{b}$ & 16.00 & 0.37 \\
\hline biceps femoris & $441 \pm 78^{b}$ & $9.33 \pm 0.90^{a}$ & $1.62 \pm 0.22^{3}$ & $159 \pm 26^{b c}$ & $441 \pm 68^{b}$ & 17.40 & 0.34 \\
\hline triceps brachii & $440 \pm 76^{b}$ & $6.23 \pm 1.06^{b c}$ & 1. $22 \pm 0.22^{\mathrm{ab}}$ & $126 \pm 30^{\text {bc }}$ & $400 \pm 45^{\circ}$ & 19.55 & 0.46 \\
\hline infraspinatus & $416 \pm 56^{b}$ & $6.26 \pm 0.94^{\mathrm{bc}}$ & 1. $30 \pm 0.11^{\mathrm{ab}}$ & $144 \pm 27^{\mathrm{bc}}$ & $296 \pm 24^{c}$ & 20.79 & 0.34 \\
\hline gluteus medius & $413 \pm 74^{\mathrm{b}}$ & $4.34 \pm 0.73^{\circ}$ & $0.98 \pm 0.08^{b}$ & $101 \pm 20^{\circ}$ & $482 \pm 51^{\mathrm{ab}}$ & 20.61 & 0.81 \\
\hline longissimus dorsi & $384 \pm 54^{\mathrm{b}}$ & 4. $91 \pm 0.53^{c}$ & $1.07 \pm 0.15^{\mathrm{b}}$ & $114 \pm 25^{c}$ & $485 \pm 97^{\text {ab }}$ & 21.76 & 0.72 \\
\hline
\end{tabular}

${ }^{1}$ Results are expressed as mean \pm SD of 30 to 80 determinations. Both values of heat solubility of collagen and uronic acid/hydroxyproline are expressed as mean.

$a, b, c$ : Means in the same vertical row with different superscripts are significantly different $(P<0.05)$. 
$\mathrm{g}$ wet muscle tissues in GM to $9.33 \pm 0.90 \mathrm{mg} / \mathrm{g}$ in BF. The toughest ST had a significantly higher collagen concentration than the most tender $\mathrm{LD}(\mathrm{P}<0.05)$. However, no definite relationship between meat toughness and the total collagen content could be observed, because $\mathrm{BF}$ contained significantly more collagen in spite of showing relatively tender meat. Collagen, occupying about $25 \%$ of total protein in the mammalian body, is also a major constituent of intramuscular connective tissues such as perimysium and endomysium, but it quantitatively only comprises less than $1 \%$ of the total weight of wet muscle tissues.

Heat-labile collagen contents ranged from $0.88 \pm 0.15 \mathrm{mg} / \mathrm{g}$ in $\mathrm{SM}$ to $1.62 \pm 0.22 \mathrm{mg} / \mathrm{g}$ in BF. However, there was little variation in the heatlabile collagen content (Table 1). This finding indicates that heat-labile collagen content in muscles could not be applied as a parameter for the determination of textural quality of meat on animals of the same age.

It was seen that the lower heat solubility of intramuscular collagen (\%), the tougher meat (Table 1). Collagen present in tender meat (LD, GM, IS) solubilized more than $20 \%$ by heating compared with $11.9 \%$ solubilization in the toughest meat (ST), which confirmed that there were more abundant heat-stable, matured crosslinks in tough meat collagen. It is apparent that collagens in intramuscular connective tissue have various types of intermolecular crosslinking ${ }^{21}$, in addition to the cystine disulfide linkage in types III and IV collagens ${ }^{6.12}$. Also, a relationship between the concentration of pyridinoline, one of matured crosslinks, and thermal stability of bovine intramuscular collagen has been reported ${ }^{23)}$, and that the proportion of matured crosslinking was higher in collagen-poor tissues, e.g. muscle, than in collagen-rich tissues, e.g. skin $^{18)}$. As shown in Table 2, significant correlations between total collagen content and heat-labile collagen content $(r=0.521, P<0.05)$ and heat solubility of collagen $(r=-0.689, P<$ 0.01 ) indicate that relatively collagen-rich muscle may have less matured crosslinks than in collagen-poor muscle in same animal. And also indicated are some contributions of proteoglycans and to stabilizing intramuscular collagen fibers or fibrils, from the findings (Table 2) of significantly negative correlations between uronic acid content and heat-labile collagen content $(r=-0.606, P<0.01)$ and heat solubility of collagen $(r=-0.440, \mathrm{P}<0.05)$. However, little information is available concerning the interactions between intramuscular connective tissue components.

Correlations between meat toughness and intramuscular connective tissue components: Fig. 1 shows the correlations between shear force value and intramusclar connective tissue components of different procine muscles. It was both heat solubility of collagen and elastin content that the best parameters had the strongest correlations with the shear force value of the raw meat $(r=-0.821, P<0.001$; Fig. $1 \mathrm{c}, \mathrm{r}=$ $0.758, \mathrm{P}<0.001 ;$ Fig. $1 \mathrm{~d}$, respectively). Significant difference in total collagen content and meat toughness was also seen $(\mathrm{P}<0.01 ;$ Fig. 1

Table 2. Linear correlation coefficients between intramuscular connective tissue components

\begin{tabular}{|c|c|c|c|c|c|}
\hline & $\begin{array}{l}\text { Heat-labile } \\
\text { collagen content }\end{array}$ & $\begin{array}{l}\text { Elastin } \\
\text { content }\end{array}$ & $\begin{array}{l}\text { Uronic acid } \\
\text { content }\end{array}$ & $\begin{array}{l}\text { Heat solubility } \\
\text { of collagen }\end{array}$ & $\begin{array}{c}\text { Uronic acid/ } \\
\text { Hydroxyproline }\end{array}$ \\
\hline Collagen content & $0.521^{* *}$ & $0.681 * *$ & 0.005 & $-0.689^{* *}$ & $-0.781^{* * *}$ \\
\hline Heat-labile collagen content & & 0.080 & $-0.606^{* *}$ & 0.236 & $-0.707^{* * *}$ \\
\hline E1astin content & & & 0.315 & $-0.655^{* *}$ & $-0.417^{*}$ \\
\hline Uronic acid content & & & & $-0.440^{*}$ & $0.574^{* *}$ \\
\hline Heat solubility of collagen & & & & & 0.338 \\
\hline
\end{tabular}

${ }^{*} \mathrm{P}<0.05, \quad{ }^{* *} \mathrm{P}<0.01, \quad{ }^{* * *} \mathrm{P}<0.001$. 


\section{Meat Toughness and Connective Tissues}

a), however, no meaningful links between textural quality of the meat and heat-labile collagen content or the proportion of uronic acid relative to hydroxyproline $(\mathrm{P}>0.05 ; \mathrm{Fig} 1 \mathrm{~b}$ and $1 \mathrm{f}$ ). These findings indicate that the predominant factors in determing meat texture may be the maturity of the fibrous connective tissue components, i.e. the amount of elastin or
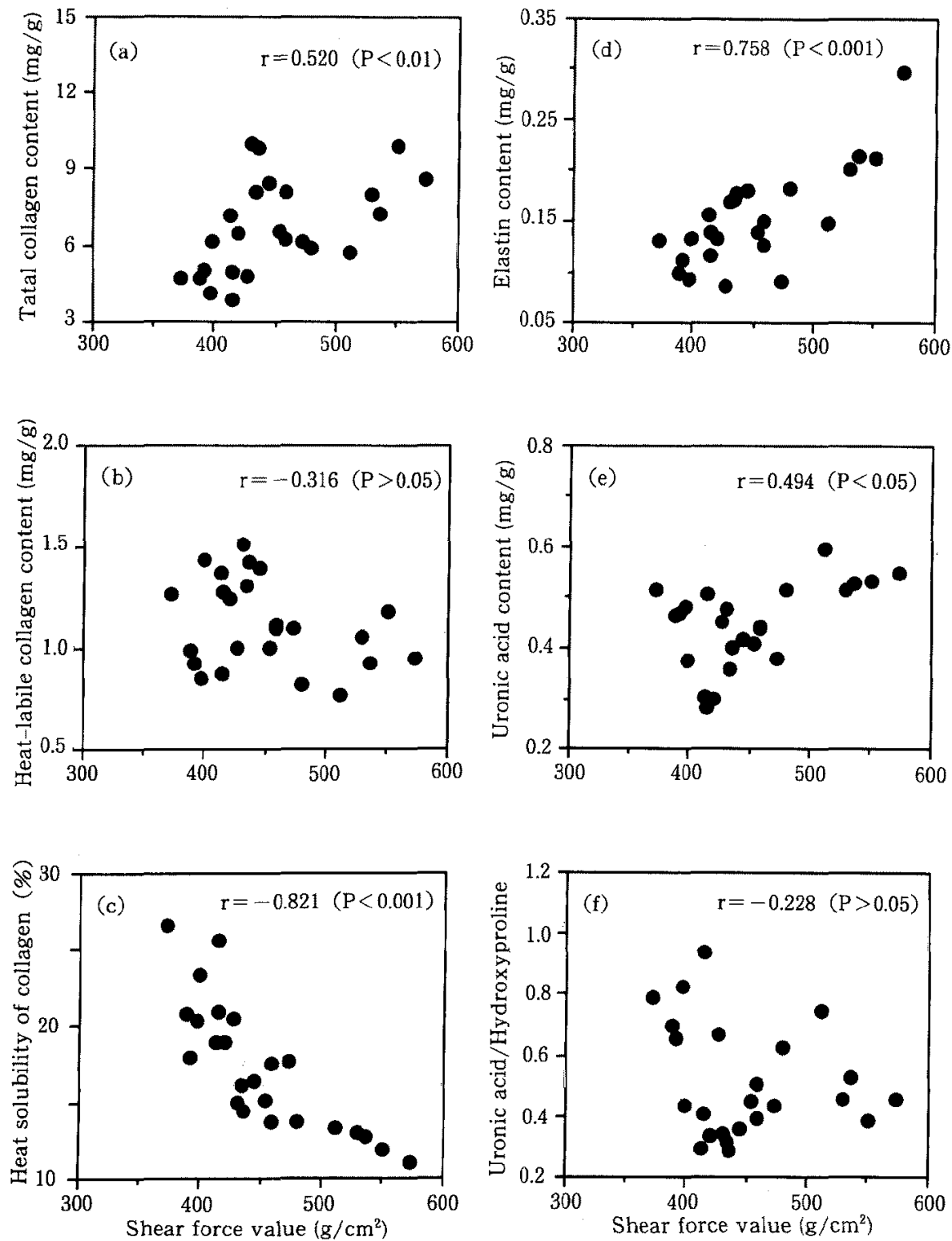

Fig. 1. Correlations between shear force value and total collagen content (a), heat-labile collagen content (b), heat solubility of collagen (c), elastin content (d), uronic acid content (e), and uronic acid/hydroxyproline (f) of eight different muscles from three miniature pigs. 
the quality of collagen, rather than the quantity of collagen present in the muscles, although DrANSFIELD ${ }^{10)}$ reported that the meat toughness was mainly influenced by the amount of total collagen. Formations of various intermolecular crosslinkings in collagen are progress. ing with the increase of animal age because of a much slower turnover of collagen, so that the steady collagen fiber in muscle or meat tend not to solubilize easily and more on heating ${ }^{21)}$. On the other hand, as the turnover of elastin is slower than that of collagen, the heating treatment could not be denatured and solubilized the elastin at al1 ${ }^{18)}$. Therefore, elastin present in this porcine muscles in very small quantities may influence the meat toughness and, especially in both cases of some specific muscles such as bovine $M$. semitendinosus in which elastin occupies $40 \%$ of the intramuscular fibrous connective tissue ${ }^{33}$ and cooked meat flowed out of a heat-denatured collagen, gelatin, it is ex* pected that elastin could play an important role in determining meat texture.

A significant correlation was also seen between uronic acid content and meat shear force value $(r=0.494, P<0.05$; Fig. $1 \mathrm{e})$; besides this, significant correlations were found between uronic acid content and heat-labile collagen content $(r=-0.606, P<0.01$ ), heat solubility of collagen $(r=-0.440, P<0.05)$, and the proportion of uronic acid relative to hydroxyproline $(r=0.574, P<0.01)$ in Table 2. These findings suggest that the intramuscular proteoglycans may not have direct effects on meat toughness but may influence the toughness indirectly by means of some action on the intramuscular collagen. Collagen fiber network is embedded in an amorphous, fexible, juicy, cement-like gel composed mainly of proteoglycans. Proteoglycans have been suggested as playing important physiological roles in water retention and electrolite control of connective tissue ${ }^{7)}$ and control of cell growth and differentiation $^{11)}$, as well as a physical role in maintenance of the tissue configuration in fetal or new-born tissues limited collagen fiber networks ${ }^{16,19)}$. Stiffness and flexibility of meat, therefore, may be controlled by the proteoglycans by means of limiting a molecular diffusion in the whole connective tissue and making collagen fibers arrange precisely.

Relationships between shear force value and individual connective tissue component in various porcine muscles were investigated in order to determine the effects of intramuscular connective tissue components on meat toughness. The present results confirm that not the quantity but the quality of collagen, such as a collagen maturity, contributes to a delicate distinction in the relative toughness of each muscle. And also, the effects of the trace components, elastin and proteoglycans on meat toughness are suggested. Both direct and indirect roles of intramuscular connenctive tissue components in determining meat texture may, therefore, appear using various techniques for analysis of types and crosslinks of intramuscular collagen, observation of threedimensional architecture of the collagen fiber network, and an elucidation of interactions among the connective tissue components.

\section{References}

1) AleXander, K.T.W., B.M. Haines and M.P. WALKER, Influence of proteoglycan removal on opening-up in the beamhouse. J. Amer. Leather Chemists Assoc., $81: 85-102.1986$.

2) Bailey, A.J., The basis of meat texture. J. Sci. Food Agric., 23 : 995-1007. 1972.

3) Bendall, J.R., The elastin content of various muscles of beef animals. J. Sci. Food Agric., $18: 553-558.1967$.

4) Bergman, I. and R. Loxley, Two improved and simplified methods for the spectrophotometric determination of hydroxy proline. Anal. Chem., $35: 1961-1965.1963$.

5) Bitter, T. and G.M. Muir, A modified uronic acid carbazole reaction. Anal. Biochem., 4: 330-334. 1962.

6) Cheung, D.T., P. DiCesare, P.D. Benya, E. Libaw and M.E. NimNI, The presence of intermolecular disulfide cross-links in type III collagen. J. Biol. Chem., 258 : 7774-7778. 1983. 
7) COMPER; W.D. and T.C. LAURent, Physiological function of connective tissue polysaccharides. Physiol. Rev., $58: 255-315.1978$.

8) Cross, H.R., G.C. Smith and Z.L. CARPenter, Quantitative isolation and partial character:zation of elastin in bovine muscle tissue. J. Agric. Food Chem., 21 : 716-721. 1973.

9) CRoss, H.R., Z.L. Carpenter and G.C. Smith, Effects of intramuscular collagen and elastin on bovine muscle tenderness. J. Food Sci., 38 : 998-1003. 1973.

10) DRANSFIELD, E., Intramuscular composition and texture of beef muscle. J. Sci. Food Agric., 28 : 833-842. 1977.

11) EdwaRd, M., H.H.K. Watson, F.B. Williamson and W.F. LoNG, Changes in glycosaminoglycans during regeneration of rat liver. Biochem. Soc. Trans., $7:$ 643-645. 1979.

12) Furthmayr, H., H. Wiedemann, R. Timpl, E. ODERMATT and J. ENGEL., Electron-microscopical apprpach to a structural model of intima collagen. Biochem. J., 211 : 303-311. 1983.

13) Goll, D.E., R.W. BRAY and W.G. Hoekstra, Age-associated changes in muscle composition. The isolation and properties of a collagenous residue from bovine muscle. J. Food Sci., $28: 503-509.1963$.

14) Hatae, K., A. Tobimatsu, M. Takeyama and J.J. Matsumoto, Contribution of the connective tissues on the texture differences of various fish muscles. Bull. Japan. Soc. Sci. Fish., 52 : 2001-2007. 1986.

15) HILL, F. The solubility of intramuscular collagen in meat animals of various age. J. Food Sci., $31:$ 161-166. 1966.

16) Nishiumi, T., F. Nakamura, T. Osugi and $K$. Kondo, Changes in connective tissue compo- nents in mink during the hair cycle and growth. Scientifur, $15: 115-122.1991$.

17) OzuTsum, K., S. Ozawa, K. Chikun, $T$. KoISHIKaWA, S. Kato, H. NAKaI, T. IKEDA, S. ANDo and M. YoShITAKE, The hardness measurement of various muscles in beef cattle via a Tensipresser. Jpn. J. Zootech. Sci., 59 : 590-595. 1988.

18) Pearson, A.M. and R.B. Young, Muscle and meat biochemistry, 338-390. Academic Press. San Diego. 1989.

19) Perlish, J.S., M.O. Logas and R. Fleischmajer, The role of glycosaminoglycans in aging of the skin. in Aging and the skin, (BALIN, A.K. and A.M. KLIGMan, eds.) 153-165. Raven Press. New York. 1989.

20) RAO, M.W. and N.F.S. GAULT, Acetic acid marination. The rheological characteristics of some raw and cooked beef muscles which contribute to changes in meat tenderness. J. Texture Studies, $21: 455-477.1990$.

21) Robins, S.P., M. Shimokomaki and A.J. BaIley, The chemistry of the collagen cross-links. Age related changes in the reducible components of intact bovine collagen fibers. Biochem. J., $131: 771-780.1973$.

22) Sims, T.J. and A.J. Balley, Connective tissue. in Developments in meat science vol. 2 (R. LAWRIE, ed.) 29-59. Applied Science. London. 1981.

23) Sмith, S.H. and M.D. Judge, Relationship between pyridinoline concentration and thermal stability of bovine intramuscular collagen. J. Anim. Sci., 69 : 1989-1993. 1991.

24) Yoshida, M., Design of Experiments for animal husbandry. 5th ed. 68-87. Youkendo. Tokyo. 1989. 
種々のブタ筋肉の硬さに対する筋肉内結合組織成分の寄与

\author{
西海理之・國䲴隆司・西村敏英・吉田 繁 \\ 広島大学生物生産学部, 東広島市 724
}

\begin{abstract}
食肉の硬さに及仿す筋肉内結合組織成分の影響を調べるために，ミニブ夕の 8 種の筋肉の剪断力値， 筋肉内コラーゲン含韵, エラスチン含量、プロテオグリカン含量, コラーゲンの加熱溶解性を测定し,

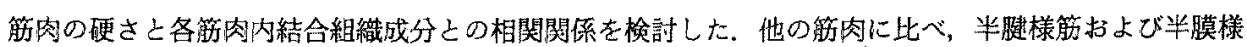
筋加有意に硬加った $(\mathrm{P}<0.05)$. 筋肉の硬さ上最む相関したのは，エラスチン含量とコラーゲンの加熱 溶解性であった $(\mathrm{P}<0.001)$. 筋肉の硬さと加熱溶解コラーゲン含量や結合組織線維成分に対する基質の 割合との間には, 全く相関がなかった $(\mathrm{P}>0.05)$. しかしながら, 筋肉の硬さと総コラーゲン含量および プロテオグリカン含量との間には，有意な相関が認められた（各々 $\mathrm{P}<0.01 ， \mathrm{P}<0.05$ ).

これらの結果から，食肉の硬さにはコラーゲンの分子間架橋などによるコラーゲンの安定化ならびに 筋肉内のエラスチンの蓄積が関与することが示唆された。
\end{abstract}

日畜会報, 66 (4)：341-348，1995 